\title{
Prevalence of Intestinal Parasites among Students of a Tertiary Institution in Jos, Nigeria
}

\author{
Ejinaka OR ${ }^{1}$, Obeta $\mathrm{MU}^{2 *}$, Jwanse $\mathrm{RI}^{3}$, Lote-Nwaru IE ${ }^{4}$, Nkop JP${ }^{1}$, Agbalaka PI ${ }^{1}$, Friday PE ${ }^{1}$ \\ ${ }^{1}$ Department of Parasitology, Federal School of Medical Laboratory Science, Jos, Nigeria; ${ }^{2}$ Department of Chemical Pathology, Federal \\ School of Medical Laboratory Science, Jos, Nigeria; ${ }^{3}$ Health and Development Support Programme (HANDS), Jos, Nigeria; \\ ${ }^{4}$ Department of Bacteriology, Federal School of Medical Laboratory Science, Jos, Nigeria
}

\begin{abstract}
A tertiary institution in Jos that admits students who are resident in the hostel where sources of water are from borehole, rain and commercial sachet water had complains from the students as a result of stomach pains and discomfort. The prevalence of intestinal parasites and most prevalent parasite among students of Federal School of Medical Science, Jos through experimental study was conducted among all the students available in the hostel of the tertiary institution in the month of September 2017 and analyzed with Percentages. Sixty faecal samples were examined for intestinal parasites by Macroscopy, Microscopy: direct and formol-ether concentration techniques. Twenty six (26) out of sixty samples were positive for intestinal parasites giving a prevalence of $43.3 \%$. The age groups 15-20 and 21-25 years had the highest prevalence of 34.6\%. Age groups between 31-35 had the lowest of 3.8\%. Parasites identified were Ascaris lumbricoides (69.2\%) hookworm (15.4\%) and Schistosoma mansoni(15.4\%). This study shows that students who use borehole $(65.4 \%)$ were more infected than those drinking rain water $(15.4 \%)$ and sachet water (19.2\%). The prevalence in males were $(26.9 \%)$ and females $(73.1 \%)$ than those who washed their vegetables (23.1\%). Students of Federal School of Medical Laboratory Science, Jos had a parasite prevalence of $43 \%$ of which Ascaris lumbricoides was more prevalent (69.2) followed by Hookworm (15.4) and Schistosoma mansoni (15.4). The management of the school should provide safe water and adequate education for prevention.
\end{abstract}

Keywords: Prevalence; Parasites; Students; Tertiary institution; Jos

\section{INTRODUCTION}

Intestinal parasitic infection is one of the major health problems in developing countries which affect up to 3.5 billion people globally and 450 million are thought to be ill as a result of such infections, the majority being children [1].

Infections by soil transmitted helminths have been increasingly recognized as an important public health concern, particularly in developing countries. Due to this significance, there have been regular endeavor to determine the present figures for soil transmitted helminths (STH) infections in Nigeria [2]. Worm transmission is enhanced by poor socio economic conditions, deficiencies in sanitary facilities, improper disposal of human faeces, insufficient supplies of portable water, poor personal hygiene, substandard housing and lack of education [3].

Work carried out by Rajeswari et al. [4], on fecal specimen with 456 children in Gombak, Malaysia, revealed an overall prevalence rate of parasites at $62.9 \%$ as most common parasite found was Trichuris trichiura $47.1 \%$ followed by Giardia intestinalis 14.7\%, Entamoeba coli, 11.4\%, Entamoeba histolytica 9.9\% and Ascaris lumbricoides, $7.9 \%$.

Infection rates were high among Indonesian immigrant workers children $90 \%$ followed by the Orang Asli 79.5\%, Malaysia $59.4 \%$ and Indians $36.4 \%$. The study also revealed that females (66.3\%) had a higher prevalence rate than the males $(58.5 \%)$. The prevalence of infection was found to be associated with the

"Correspondence to: Obeta Uchejeso, Department of Chemical Pathology Federal School of Medical Laboratory Science, PMB 2253, Jos Plateau State, Nigeria, Tel: +234 8088741364; E-mail: uchejesoobeta@gmail.com

Received: June 01, 2019; Accepted: July 02, 2019; Published: July 09, 2019

Citation: Ejinaka OR, Obeta MU, Jwanse RI, Lote-Nwaru IE, Nkop JP, Agbalaka PI, et al. (2019) Prevalence of Intestinal Parasites among Students of a Tertiary Institution in Jos, Nigeria. J Bacteriol Parasitol. 10:360.

Copyright: (C) 2019 Ejinaka OR, et al. This is an open-access article distributed under the terms of the Creative Commons Attribution License, which permits unrestricted use, distribution, and reproduction in any medium, provided the original author and source are credited. 
socio-economic status, water supply, sanitary disposal of faeces and family size [5].

Holland et al. [6] carried out epidemiological survey of intestinal helminthiasis among children aged 5-16 years in Ile-Ife, Nigeria and found the prevalence of Ascaris lumbricoides, Trichuris trichura, Ankylostoma duodenale and Strongyloides stercoralis to be $88.5 \%$, $84.5,33.1$ and $3 \%$ respectively.

The study is aimed to investigate the prevalence of intestinal parasites and demographic factors associated with source of drinking water in a tertiary institution in Jos.

\section{MATERIALS AND METHODS}

\section{Study area}

Federal school of medical laboratory science is located in Jos, the capital of Plateau State. Plateau is at an elevation of about 1,238 meters or 4,062 feet high above sea level. The Jos North Local Government is situated in the semi-arid region of the middle belt of Nigeria. It is located at latitude of $9056 \mathrm{~N}-805$.E/ 9,9330N8.8. It is about 179 kilometers (111 miles) from Abuja, the nation's capital. Jos is linked by road, rail and air to the rest of the country (Wikipedia, 2017).

\section{Study approval}

The study was approved by the Institutional Ethical Committee and Academic Board of Federal School of Medical Laboratory Science, Jos. Informed consent was also sought from the students before carrying out the study.

\section{Settings and design}

A cross sectional study with experimental design was conducted among all the students available in the hostel based on the availability during the study in the month of September 2017.

\section{Sample size}

The sample population was the entire students of the institution considering that all the students were Eighty eight (88) in number. The sample size was Sixty (60) students, considering that some were not available during sample collection and those leaving outside the hostel were excluded from the research.

\section{Sample collection}

Sixty (60) stool samples were collected in a clean, wide-mouthed, screw cap, transparent, dry and disinfectant free bottle. They were well labeled with the students name, sex, age, school and date. The students were instructed on how the sample should be collected so as to avoid contaminating the stool sample with urine or soil to avoid false positive result.

The specimen bottles were randomly given to each student. The stool samples were collected in September 2017 and relevant information on source of drinking water and type of toilet were collected with the aid of pretested structured questionnaires. The samples were taken to the laboratory of Federal School of Medical Laboratory Science, Jos for immediate examination

\section{Method of analysis}

Macroscopic examination and Microscopic examination were adequately carried out by Direct Wet Mount examination, Iodine Wet Mount and Formol-Ether Concentration Technique as earlier described by authors [7-9]. The adult warms, warm segments, larvae, cyst and eggs that were seen during the examinations of the specimens were recorded.

\section{Statistical analysis}

The results were analyzed in percentages.

\section{RESULTS}

The results of the study are presented in Tables 1-6.

Table 1: Total Prevalence of Intestinal Parasite among students.

\begin{tabular}{lll}
\hline Number examined & Number Positive $(+)$ & Prevalence (\%) \\
\hline 60 & 26 & 43.3 \\
\hline
\end{tabular}

26 were positive for intestinal parasites giving a prevalence of $43.3 \%$.

Table 2: Prevalence of intestinal parasite among student in relation to their sex.

\begin{tabular}{llll}
\hline Gender & Number examined & Number Positive $(+)$ & Prevalence (\%) \\
\hline Male & 23 & 7 & 26.9 \\
\hline Female & 37 & 19 & 73.1 \\
\hline Total & 60 & 26 & 100 \\
\hline
\end{tabular}

7 were positive among male students giving a prevalence of $26.9 \%$ and 17 were positive among female students giving the prevalence of $73.1 \%$ for intestinal parasites. 
Table 3: Prevalence of Intestinal Parasites among student in relation to their age group.

\begin{tabular}{llll}
\hline Age group (years) & Number examined & Number Positive $(+)$ & Prevalence (\%) \\
\hline $15-20$ & 10 & 9 & 34.6 \\
\hline $21-25$ & 30 & 9 & 34.6 \\
\hline $26-30$ & 16 & 7 & 26.9 \\
\hline $31-35$ & 4 & 1 & 3.8 \\
\hline Total & 60 & 26 & 100 \\
\hline
\end{tabular}

The age groups of $15-20$ and $21-25$ were having a high prevalence of $34.6 \%$, while those of the age group $31-35$ had a prevalence of $3.8 \%$ of intestinal parasites.

Table 4: Prevalence of intestinal parasite in relation to source of drinking water.

\begin{tabular}{llll}
\hline $\begin{array}{l}\text { Source of drinking } \\
\text { water }\end{array}$ & $\begin{array}{l}\text { Number } \\
\text { examined }\end{array}$ & $\begin{array}{l}\text { Number } \\
\text { Positive }(+)\end{array}$ & $\begin{array}{l}\text { Prevalence } \\
(\%)\end{array}$ \\
\hline Borehole & 27 & 17 & 65.4 \\
\hline Rain water & 8 & 4 & 15.4 \\
\hline Sachet water & 25 & 5 & 19.2 \\
\hline Total & 60 & 26 & 100 \\
\hline
\end{tabular}

Those that drank borehole water had the highest prevalence of $65.4 \%$ followed by those who drank sachet water with the prevalence of $19.2 \%$ and those who took rain water in the lowest with the prevalence of $15.4 \%$.

Table 5: Prevalence of different intestinal parasite among students.

\begin{tabular}{lll}
\hline Parasite & Number Positive $(+)$ & Prevalence (\%) \\
\hline Ascaris lumbricoides & 18 & 69.2 \\
\hline Hook worm & 4 & 15.4 \\
\hline Schistosoma mansoni & 4 & 15.4 \\
\hline Total & 26 & 100 \\
\hline
\end{tabular}

Three (3) parasites encountered Ascaris lumbricoides with the prevalence of $69.2 \%$ followed by hookworm and Schistosoma masoni which had the prevalence of $15.4 \%$ each.
Table 6: Prevalence of Intestinal Parasites among students in relation to washing of vegetables before consumption.

\begin{tabular}{lcll}
\hline $\begin{array}{l}\text { Students that washed/ } \\
\text { unwashed }\end{array}$ & $\begin{array}{l}\text { Number } \\
\text { examined }\end{array}$ & $\begin{array}{l}\text { Number } \\
\text { Positive }(+)\end{array}$ & $\begin{array}{l}\text { Prevalence } \\
\text { (\%) }\end{array}$ \\
\hline $\begin{array}{l}\text { Number that washed } \\
\text { Number that doesn't }\end{array}$ & 27 & 6 & 23.1 \\
\hline $\begin{array}{l}\text { Nash } \\
\text { Total }\end{array}$ & 60 & 20 & 76.9 \\
\hline
\end{tabular}

33 students washed vegetables with a prevalence of $23.1 \%$ and 27 students did not wash vegetables with a high prevalence of $76.9 \%$.

\section{DISCUSSION}

This study carried out among students of Federal School of Medical Laboratory Science to determine the prevalence of intestinal parasites showed a high prevalence of $43.3 \%$. This agrees with Hailegebriel [10] and Ismail [11] especially with high prevalence of parasites in developing countries. In consideration of gender of students in this study, the female students having a higher population of 37 as opposed to 23 males students from the study, out of 37 stool samples examined the from the females 19 were positive for intestinal parasites giving a prevalence of $73.1 \%$ while from the result of 23 stool samples examined for the males only 7 were positive giving a prevalence of $26.9 \%$. This shows that the female has more intestinal parasites than the males and the study agrees with that of Capello et al. [5], in relation to gender. This further infers that female student had more parasitic infection than the males.

In relation to age group students within the age group of 15-20 years were positive for intestinal parasites with a 9 positive sample out of 10 examined (34.6\%). Age range between $21-25$ years, 30 samples were examined and 9 was positive (34.6\%). For age range between $26.30,7$ samples were positive out of the 16 samples examined $(26.9 \%)$ and lastly for age range between $31-35$ only 1 sample was positive out of the 4 examined (3.8\%). This shows that age ranges between 15-20 and 21-25 had a higher prevalence.

The prevalence in relationship to source of drinking water, 27 was the highest with 17 positive $(65.4 \%)$ followed by these who takes sachet water with 25 examined and 5 positive (19.2\%) 
while for rain water 8 were examined and only 4 positive (15.4\%). This shows that more student use borehole water which is the major source of drinking water. Researchers have raised alarm on the safety of drinking water [12,13] and vegetables [14,15] with regards to parasitic infection while enumerating the importance of vegetables and need for adequate washing and cooking.

For the prevalence in relationship to the different intestinal parasites only 3 groups of parasites were found with Ascaris lumbricoides recording the highest with 18 positive followed by Hookworm which is four (4) and Schistosoma mansoni which is also 4. Schistosoma mansoni could be as a result of students coming from village where water bodies are found such as mining ponds as in Plateau State.

Ascaris lumbricoides has being shown to be the highest in prevalence by researchers [16-19], and the major route of transmission being ingestion of contaminated food, water and vegetables and this calls for so much concern for elimination and control.

Students of Federal School of Medical Laboratory Science, Jos were more prone to intestinal parasites and have a parasite prevalence of $43 \%$ of which Ascaris lumbricoides is more prevalent (69.2) followed by Hookworm (15.4) and Schistosoma mansoni (15.4). This is related to Holland et al. [6] work though reduced in prevalence. The reduction may be as a result of the age difference as the children assessed in Ile-Ife was between 5-16 years while the students assessed in this institution had age range of $15-20$ years with 15-25 years having the highest prevalence. This suggests an age-hygiene relationship considering lower prevalence when compared to the study in Ile Ife [6].

\section{CONCLUSION}

Students of Federal School of Medical Laboratory Science, Jos were more prone to intestinal parasites and has a parasite prevalence of $43 \%$ of which Ascaris lumbricoides is more prevalent (69.2) followed by Hookworm (15.4) and Schistosoma mansoni (15.4). The parasite prevalence is more in females (73.1\%), more prevalent in ages between 15-25 (69.2\%) and borehole water has the prevalence of $65.4 \%$. These calls for public health scientists and practitioners provide a solution to the students and management of the School.

This study therefore recommends the following punitive measures to be taken in alleviating most of the teething problems regarding parasitic infections thereby creating a parasite free tertiary institution in Jos:

- Drinking water from a good source or that the borehole should be treated by the management of Federal School.

- Proper washing of food items especially vegetables before eating have being highly advocated $[20,21]$.

- Adequate de-worming at most every 3 month is required.

- Eating of balanced diet to build up immunity to fight parasitic infections e.g. hookworm.

- Adequate fumigation and destruction of snail intermediate host in water bodies around the institution.

\section{REFERENCES}

1. WHO. Intestinal protozoa and Helminths infection. WHO Technical Report Series, 2016:916.

2. WHO. Prevention and Control of Intestinal Parasites. WHO Technical Report Series, 2012: 739.

3. Nock, Duriya IH, Galadima M. Geohelminths eggs in soil and stool of pupils of some primary schools in Samaru, Zaria. Nig J Parsitology. 2003;24(1):115-122

4. Rajeswari B, Sinniah B, Hussein H. Socio-economic factors associated with intestinal parasites among children living on Gombak, Malaysia. Asia Pac J Public Health. 1994;7(1):21-5.

5. Capello M. Global impact of soil transmitted nematodes (chapter 16) Human parasitology. UK: Academic Press. 2004;269-345.

6. Holland CV, Asaolu SO, Crompton DW, Stoddart RC, Macdonald R, Torimiro SE. The Epidemiology of Ascaris lumbricoides and other Soil transmitted Helminths in Primary School Children in Ile-Ife, Nigeria. Parasitology. 1989;99(2): 275-285.

7. Cheesbrough M. Medical Laboratory Manual for Tropical Countries, 2nd Edition. University Press Cambridge 1992; 206-207.

8. Tankeshwar Formal Ether Sedimentation Technique for the Concentration of Stool Parasites.

9. Damen JG, Banwat E B, Egah DZ, Allanana JA. Parasitic contamination of vegetables in Jos, Nigeria. Ann Afr Med. 2007;6(3):115-118.

10. Hailegebriel T. Prevalence of intestinal parasitic infections and associated risk factors among students at Dona Berber primary school, Bahir Dar, Ethiopia. BMC Infect Dis.2017;17:362.

11. Ismail KA. Prevalence of Intestinal Parasitic Infection among School Children in Taif. Insights Biomed. 2018;3(2):10.

12. Adewale B, Rahaman O, Aina O, Sulyman MA. Schistosoma mansoni and Soil Transmitted Helminth (STH) Infections among Pregnant Women Attending Primary Health Care Facilities in Lagos Mainland, Nigeria. J Biosci Medicines. 2006;6(12):64-70.

13. Ejinaka OR, Obeta, MU,Agbalaka PI, Ajik H. Current review of diagnosis and control of urogenital schistosomiasis. The Diagnostics. 2019;3(1):40-57.

14. Agbalaka PI, Ejinaka OR, Yakubu DP, Obeta UM, Jwanse RI, Dawet A. prevalence of parasites of public health significance in vegetables sold in Jos Metropolis, Plateau State, Nigeria. Am J Public Health. 2019;7(2):48-57.

15. Agbalaka PI, Yakubu D, Ejinaka OR, Obeta MU, Dawet A. Prevalence of parasites of public health significance in vegetables sold in jos metropolis, Plateau State, Nigeria. Scientific Paper Presentation at 54th AMLSN Conference; Book of Abstract Rock City, 2018.

16. Galgamuwa LS, Iddawela D, Dharmaratne SD. Prevalence and intensity of Ascaris lumbricoides infections in relation to undernutrition among children in a tea plantation community, Sri Lanka: a crosssectional study. BMC Pediatr. 2018;18(1):13.

17. Dold C, Celia V. Ascaris and ascariasis. Microbes Infect. 2011;13(7):632-637.

18. Crompton DW. Ascaris and ascariasis. Adv Parasitol. 2001;48:285-375.

19. De Silva NR, Brooker S, Hotez PJ, Montresor A, Engels D, Savioli L. Soil transmitted helminth infections: updating the global picture. Trends Parasitol. 2003;19(12):547-551.

20. Bundy DAP, Kremer M, Bleakley H, Jukes MCH, Miguel E. Deworming and development: asking the right questions, asking the questions right. PLoS Negl Trop Dis. 2009 :3 (1):e362.

21. WHO. Prevention and Control of Schistosomiasis and Soiltransmitted Helminthiasis: Report of a WHO Expert Committee, Technical Report Series 912, 2002;1-57. 